\title{
Identification and Characterization of the ATG8, a Marker of Eimeria tenella Autophagy
}

\author{
Identificação e Caracterização do ATG8, um marcador de autofagia em Eimeria tenella

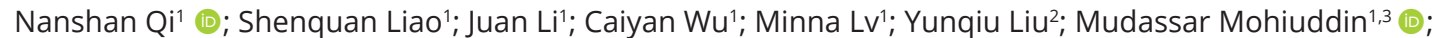

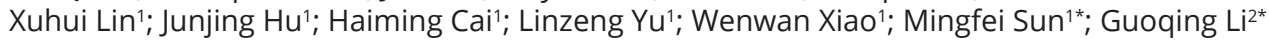

\begin{abstract}
${ }^{1}$ Key Laboratory of Livestock Disease Prevention of Guangdong Province, Maoming Branch, Guangdong Laboratory for Lingnan Modern Agriculture, Scientific Observation and Experiment Station of Veterinary Drugs and Diagnostic Techniques of Guangdong Province, Ministry of Agriculture, Institute of Animal Health, Guangdong Academy of Agricultural Sciences, Guangzhou 510640, Guangdong, P. R. China

${ }^{2}$ College of Veterinary Medicine, South China Agricultural University, Guangzhou 510642, Guangdong, P R China
\end{abstract} \\ ${ }^{3}$ Department of Microbiology, Faculty of Veterinary and Animal Sciences, The Islamia University of Bahawalpur, Bahawalpur 63100, \\ Pakistan
}

How to cite: Qi N, Liao S, Li J, Wu C, Lv M, Liu Y, et al. Identification and Characterization of the ATG8, a Marker of Eimeria tenella Autophagy. Braz J Vet Parasitol 2021; 30(1): e017020. https://doi.org/10.1590/S1984-29612021002

\begin{abstract}
Autophagy plays an important role in maintaining cell homeostasis through degradation of denatured proteins and other biological macromolecules. In recent years, many researchers focus on mechanism of autophagy in apicomplexan parasites, but little was known about this process in avian coccidia. In our present study. The cloning, sequencing and characterization of autophagy-related gene (Etatg8) were investigated by quantitative real-time PCR (RT-qPCR), western blotting (WB), indirect immunofluorescence assays (IFAs) and transmission electron microscopy (TEM), respectively. The results have shown 375-bp ORF of Etatg8, encoding a protein of 124 amino acids in E. tenella, the protein structure and properties are similar to other apicomplexan parasites. RT-qPCR revealed Etatg8 gene expression during four developmental stages in E. tenella, but their transcriptional levels were significantly higher at the unsporulated oocysts stage. WB and IFA showed that EtATG8 was lipidated to bind the autophagosome membrane under starvation or rapamycin conditions, and aggregated in the cytoplasm of sporozoites and merozoites, however, the process of autophagosome membrane production can be inhibited by 3-methyladenine. In conclusion, we found that $E$. tenella has a conserved autophagy mechanism like other apicomplexan parasites, and EtATG8 can be used as a marker for future research on autophagy targeting avian coccidia.
\end{abstract}

Keywords: Eimeria tenella, autophagy, ATG8, clone and expression, characterization.

\begin{abstract}
Resumo
A autofagia desempenha um papel importante na manutenção da homeostase celular através da degradação de proteínas desnaturadas e outras macromoléculas biológicas. Nos últimos anos, muitos pesquisadores se concentraram no mecanismo da autofagia em parasitas apicomplexos, mas pouco se sabe sobre esse processo na coccidia aviária. No presente estudo, a clonagem, sequenciamento e caracterização de gene relacionado à autofagia Etatg8 foram investigados pela PCR quantitativa em tempo real (RT-qPCR), mancha ocidental (WB), ensaios indiretos de imunofluorescência (IFAs) e microscopia eletrônica de transmissão (TEM), respectivamente. Os resultados mostraram que o gene Etatg8 de E. tenella possui uma ORF de 375 bp, codificando uma proteína de 124 aminoácidos com estrutura e propriedades semelhantes à de outros apicomplexos. RT-qPCR revelou que Etatg8 é expresso durante os quatro estágios de desenvolvimento de E. tenella. Entretanto, seus níveis transcricionais foram significativamente mais elevados na fase de oocisto não esporulados. Os ensaios de manchas ocidental (WB) e de imunofluorescência (IFA) mostraram que a proteína EtATG8 foi lipidada para ligar-se à membrana do autofagossomo sob condições de deficiência nutritiva (em presença de rapamicina) e se agregar no citoplasma de esporozoítas e merozoítas. No entanto, o processo de produção de membrana do autofagossomo pode ser inibido por um inibidor de autofagia (3-meetiladeninatiladenina, 3-MA). Em conclusão, foi demonstrado que $E$. tenella tem um mecanismo de autofagia conservado, semelhante ao de outros parasitas apicomplexos, e que EtATG8 pode ser usado como um marcador para futuras pesquisas sobre autofagia direcionada à coccidiose aviária.

Palavras-chave: Eimeria tenella, autofagia, ATG8, clone e expressão, caracterização.
\end{abstract}




\section{Introduction}

Avian coccidiosis, a parasitic disease, can be caused by intestinal infection with seven Eimeria species, namely; E. tenella, E. necatrix, E. acervulina, E. maxima, E. brunetti, E. mitis and E. praecox (Liu D et al., 2014). The infection is seriously harmful to the intestinal health of chickens, and inflicts huge economic losses to the poultry industry worldwide (Quiroz-Castañeda \& Dantán-González, 2015; Tan et al., 2017). Chemoprophylaxis (ionophores and other chemicals) and vaccination (live attenuated or unattenuated vaccines) are the two major preventive strategies against coccidiosis, however, owing to emergence of resistant Eimeria strains and drug residue problems, there arise a need to explore future alternatives (Clark et al., 2017; Peek \& Landman, 2011; Tan et al., 2017). Moreover, increasing public health concerns have put a question mark on the prophylactic use of drugs in food-producing animals and consequently restrictions are imposed for their usage in the developed world (Blake \& Tomley, 2014; Quiroz-Castañeda \& Dantán-González, 2015). Although, live vaccines are a major alternative for the effective control of coccidiosis, but their complex production processes, short-term storage issues, and the risk of the vaccine strains regaining their original pathogenicity, have limited their development and application (Tang et al., 2019; Qi et al., 2013; Tewari \& Maharana, 2011). Thus, the discovery of new anticoccidial drugs and vaccines has become an urgent need in addition to the other alternatives for prevention and control of avian coccidiosis.

Autophagy, a "self-eating" process in eukaryotic cells, is involved in targeted degradation of damaged or senescent cells, organelles, denatured proteins, nucleic acids and other biological macromolecules for maintaining cell homeostasis (Brennand et al., 2011; Mizushima et al., 2010; Yu et al., 2018), including organelle clearance during cell differentiation and progression (Besteiro, 2012). This mechanism is evolutionarily conserved across all eukaryotes, including apicomplexan parasites (Latré de Laté et al., 2017; Sinai \& Roepe, 2012) and several studies have proven the mechanism of autophagy in apicomplexan parasites is activated in response to starvation or anticoccidial drugs, which leads to programmed cell death (Besteiro, 2017). Thus, induction of autophagy in parasites could be a novel approach for the future anti-parasitic therapeutics.

Currently, more than 40 autophagy-related proteins (ATG) have been identified in eukaryotic cells; most of them are evolutionarily conserved from protozoans to mammals, having vital functions in the accomplishment of programmed cell death (Besteiro et al., 2011). For example, ATG5-ATG12 complex and ATG7-ATG3 complex are involved in autophagosome formation, the ATG17-ATG29-ATG31 complex is a pre-autophagosomal structure (PAS) formation, Beclin1-Vps34 complex is the main regulator of autophagy, ATG15, ATG22 and PEP4 in the breakdown of autophagy, and ATG22 and ATG33 are closely related to the formation of mitophagy (Meijer et al., 2007). ATG8, a key ubiquitin-like protein, can bind the autophagosome membrane after being activated by ATG3 and ATG7 (Yamaguchi et al., 2010), and has been considered as a marker for studies on autophagy.

Many autophagy studies on apicomplexans have shown that the biochemical function of ATG8 is conserved across all eukaryotes (Tomlins et al., 2013), but there are two views on the subcellular localization of ATG8; some researchers agree that ATG8 is localized in the apicoplasts of some parasites, and participates in the formation of apicoplast membranes (Walczak et al., 2018), while others think that it should be distributed in the cytoplasm, and ATG8-related punctate structures may exist in the cytoplasm under starvation or autophagy-induced treatment, which can be used as a marker for detecting autophagosomes (Sinai \& Roepe, 2012). However, very little is known about autophagy in E. tenella. In a previous study, we identified about 11 ATG gene orthologs in E. tenella genome database (ETH_00016760, ETH_00018400,ETH_00011205, ETH_00021095, ETH_00032225, ETH_00019020, ETH_00038935, ETH_00030035, ETH_00026430, ETH_00026880, ETH_00041360), including Etatg8 (ETH_00016760) conserved in E. tenella and other apicomplexans. In the present study, we report the cloning, sequencing expression and characterization of Etatg8 of E. tenella, which will provide new insight for autophagy studies in Eimeria relevant to the prevention and control of avian coccidiosis.

\section{Materials and methods}

\section{Ethics approval}

The study was conducted with the approval of China Guangdong Province Science and Technology Department (Permit Number: SYXK (Yue) 2016-0165).

\section{Parasites and animals}

The E. tenella GD strain used in this study was isolated from a ceca sample obtained at a chicken farm in Guangdong, China. Oocysts were passaged in 2-week-old Lingnan Yellow chickens for 7 days by infecting them 
with $5 \times 10^{4}$ sporulated oocysts. The chicks (day-old hatchlings) were purchased from Guangdong WIZ Agricultural Science \& Technology Co., Ltd. (Guangzhou, China). The oocysts were harvested and purified as described previously, and the saturated salt solution used as floatation solution (Qi et al., 2019; Sun et al., 2016). The free sporozoites prepared from sporulated oocysts by in vitro excystation were purified by passage through a G3 filter funnel (lingke, Guangzhou, China). Merozoites were collected from ceca of chickens that had been infected with $5 \times 10^{4}$ sporulated oocysts per chicken at $120 \mathrm{~h}$ post-infection. The purification procedure was the same as previously described (Sun et al., 2016).

\section{Transmission electron microscopy (TEM)}

Following incubation in Dulbecco's modified Eagle' s medium (DMEM) or Hank' s balanced salt solution (HBSS) at $41^{\circ} \mathrm{C}$ for $8 \mathrm{~h}$, the $E$. tenella sporozoites were fixed in $2.5 \%$ glutaraldehyde with $4 \%$ parafomaldehyde in $0.1 \mathrm{M}$ cacodylate buffer for $3 \mathrm{~h}$ followed by post fixation in $1 \%$ osmium tetroxide for $3 \mathrm{~h}$. Parasites were dehydrated in a series of ethanol formulations followed by $100 \%$ epoxy ethane, infiltrated with Spurr's resin and polymerized for $12 \mathrm{~h}$ at $70{ }^{\circ} \mathrm{C}$. Ultra-thin sections $(70 \mathrm{~nm})$ were placed and stained with $1 \%$ uranyl acetate or $0.25 \%$ lead citrate, then observed with HT7700 transmission electron microscope (TEM, HITACHI, Japan).

\section{RNA extraction and RT - PCR amplification}

The homologous gene to Etatg8 (ETH_00016760) was used to design specific primers (Table 1) for amplifying the open reading frame of Etatg8 gene. Total RNA was extracted from the four life stages of E. tenella (unsporulated oocysts, sporulated oocysts, sporozoites and merozoites) using the HiPure Total RNA Micro kit (MAGEN, China). The RNA was treated with DNase I (Takara), and cDNA was generated from it using PrimeScript II 1st Strand cDNA Synthesis kit (Takara) with random primers. The Etatg8 gene was PCR-amplified by using LATaq®DNA polymerase (Takara) using following procedure: an initial denaturation at $95^{\circ} \mathrm{C}$ for $5 \mathrm{~min}$, followed by $35 \mathrm{cycles}$ of $95^{\circ} \mathrm{C}$ for $30 \mathrm{~s}, 55^{\circ} \mathrm{C}$ for $30 \mathrm{~s}, 72^{\circ} \mathrm{C}$ for $30 \mathrm{~s}$, and a final elongation at $72^{\circ} \mathrm{C}$ for $7 \mathrm{~min}$. The PCR products were analyzed by $3 \%$ agarose gel electrophoresis.

Table 1. Primer sequences used for PCR in this study.

\begin{tabular}{ccc}
\hline Gene ID & Forward primer (5'-3') & Reverse primer (5'-3') \\
\hline RT-PCR (Etatg8) & ATGCCTTCCATAAGAGATGAGAT & TTATCCGAGAGTATTTTCTGCG \\
Expression (rEtATG8) & GGCGGATCCATGCCTTCCATAAGAG-ATGAGAT & GGCAAGCTTTTATCCGAGAGTATTT-TCTGCG \\
qPCR (Etatg8) & TGCCTTCCATAAGAGATGAGATTTC & CTGGTTGATGTGTTTGTGGATTATG \\
qPCR (Etactin) & CACCACCGCCGAGAAAGA & GAACAACATTGCCGTAGAGG \\
\hline
\end{tabular}

\section{Cloning, sequencing and bioinformatics analysis}

PCR products purified using Gel Extraction Kit (OMEGA) were cloned using the pMD18-T Vector Cloning kit (Takara) following the manufacturer's instructions, then transformed into DH5a chemically competent cells (Transgen Biotech, China). The positive clones identified by PCR (same protocol as PCR-amplification) were sent to Invitrogen (China) biotechnology company for sequencing, the sequences were analyzed using the SignalP 4.1 (http://www. cbs.dtu.dk/services/SignalP/), the TMHMM Server v. 2.0 (http://www.cbs.dtu.dk/services/TMHMM-2.0/) for protein signal peptide, protein transmembrane domain and protein structure identification, respectively. In addition, the TargetP 1.1 server (http://www.cbs.dtu.dk/services/TargetP/) was used for predicting the subcellular location of the protein, and the basic local alignment search (BLAST, http://blast.ncbi.nlm.nih.gov/Blast.cgi) and MEGA 5.05 (Tamura et al., 2011) were used for molecular phylogenetic analysis.

\section{Expression and purification of recombinant EtATG8}

Protein expression and purification was conducted as described previously (Sun et al., 2016). Briefly, the Etatg8 open reading frame was amplified by PCR with primers which incorporated EcoRI and Xhol restriction sites (Table 1). The PCR product was cloned into the pET28a expression vector (Novagen, Darmstadt, Germany), and recombinant EtATG8 (rEtATG8) with an N-terminal His tag was expressed in the Escherichia coli BL21 strain, and then purified under denaturing conditions by Ni-NTA column chromatography (Novagen) according to the manufacturer's instructions. The target protein $(100 \mu \mathrm{g}$ ) was separated by sodium dodecyl sulfate polyacrylamide gel electrophoresis (SDS-PAGE) on $12 \%$ gels and visualized after staining with coomassie brilliant blue, and detected by Western Blotting (WB) using a mouse anti-His-Tag moloclonal antibody (diluted 1:1000, Cwbiotech, China) and goat anti-mouse IgG-HRP (diluted 1:2000, Santa Cruz Biotechnology, USA). 


\section{Production of polyclonal anti-rEtATG8 antibodies}

Rabbit anti-rEtATG8 serum was prepared as described previously (liang et al., 2012). Briefly, four-month-old female rabbits were immunized four times at 2-week intervals with rEtATG8 (1.0 mg/rabbit), which was emulsified in complete Freud's adjuvant for first immunization. The second, third and fourth immunizations used rEtATG8 $(0.5 \mathrm{mg} / \mathrm{rabbit})$ emulsified in incomplete Freud's adjuvant. Polyclonal rabbit anti-rEtATG8 antibodies were affinitypurified from the rabbit antiserum using specific antigen and then stored at $-80^{\circ} \mathrm{C}$ until use. The antibody titers were determined by enzyme-linked immunosorbent assay (ELISA).

\section{Transcriptional profile of Etatg8 in four life stages of E. tenella}

The transcriptional profile of Etatg8 in the four life stages of $E$. tenella was detected using quantitative real-time PCR (RT-qPCR) with SYBR green I (Liu R et al., 2014; Xu et al., 2008). Briefly, (Xu et al., 2008) the primers were designed using Primer Premier 5.0 (Table 1), and RT-qPCR was performed in a $20 \mu \mathrm{L}$ reaction volume containing $10 \mu \mathrm{L} 2 \times$ Taq PCR MasterMix (Takara), $1.0 \mu \mathrm{L} c D N A$, each primer $(1 \mu \mathrm{L}, 10 \mu \mathrm{M})$, and $7 \mu \mathrm{L}$ nuclease free $\mathrm{H}_{2} \mathrm{O}$, which was performed using the CFX Connect system (Bio-Rad). Nuclease free $\mathrm{H}_{2} \mathrm{O}$ and the Etactin gene were used as the negative and internal controls, all samples were run in triplicate. The amplification was performed using initial denaturation at $95^{\circ} \mathrm{C}$ for $10 \mathrm{sec}$, followed by 40 cycles of $95^{\circ} \mathrm{C}$ for $5 \mathrm{sec}$, and $60^{\circ} \mathrm{C}$ for $30 \mathrm{sec}$. Finally, the transcriptional level of the Etatg8 gene was calculated according to the $2^{-\Delta \Delta C T}$ method, the data were statistically analyzed with one-way $\operatorname{ANOVA}(p<0.05, \mathrm{n}=3)$.

\section{Protein expressional profile of EtATG8 in four life stages of E. tenella}

Total proteins from the four life stages of E. tenella were prepared using the Cell Lysis Buffer system (Beyotime, China), and the protein concentrations were determined using the BCA protein assay kit (Beyotime, China), then total protein extracts of each stage $(100 \mu \mathrm{g})$ were subsequently separated on $12 \%$ SDS-PAGE. The EtATG8 expression profile in the four life stages was determined by WB with polyclonal rabbit anti-rEtATG8 antibody (diluted 1:500). A rabbit monoclonal anti-Actin antibody (diluted 1:500, Sigma, USA) and goat anti-rabbit IgG-HRP (diluted 1:2000, SantaCruz Biotechnology, USA) was used as control and secondary antibody, respectively.

\section{Expression of EtATG8 protein instarvation- or inducer- induced sporozoites}

Following the induction of starvation and/or inducer treatment, the total proteins from sporozoites incubated in DMEM, HBSS, HBSS with 3-methyladenine (3-MA, 25 mM, Sigma, USA), DMEM with rapmycin (RP, 10 4 M, Sigma, USA), and DMEM with RP and 3-MA were prepared using the Cell Lysis Buffer system (Beyotime, China), and the protein concentrations were determined using the BCA protein assay kit (Beyotime, China), then total protein extracts of each sample $(100 \mu \mathrm{g})$ were separated on $12 \%$ SDS-PAGE with $6 \mathrm{M}$ urea to visualise the lipid-conjugated form of EtATG8, or on 12\% SDS-PAGE without urea to visualise the total EtATG8. The EtATG8 was determined by Western blot with polyclonal rabbit anti-rEtATG8 antibody (diluted 1:500, the polyclonal antibodies derived from Et ATG8-vaccinated rabbits). A rabbit monoclonal anti-Actin antibody (diluted 1:500, Sigma, USA) was used as the control, the goat anti-rabbit IgG-HRP (diluted 1:2000, SantaCruz Biotechnology, USA) was used as the secondary antibody.

\section{Indirect immunofluorescence assays}

Indirect immunofluorescence assays (IFAs) were performed either on sporozoites or on merozoites of E. tenella under different conditions as described previously (Xu et al., 2008). Briefly, the extracellular sporozoites and merozoites were harvested after being incubated in DMEM, HBSS, DMEM with rapamycin (RP, $10 \mu \mathrm{M})$, or DMEM with monensin (Mon, $100 \mathrm{ng} / \mathrm{mL}$, Sigma, USA) at $41{ }^{\circ} \mathrm{C}$ for $8 \mathrm{~h}$. The parasites were fixed for $20 \mathrm{~min}$ with $4 \%(\mathrm{w} / \mathrm{v})$ paraformaldehyde in phosphate-buffered saline (PBS), permeabilized with 1\% Triton X-100 for 10 min after being adhered onto poly-L-lysine slides for 20 min, and then blocked with $0.1 \%(\mathrm{w} / \mathrm{v})$ BSA in PBS for $30 \mathrm{~min}$ at $37^{\circ} \mathrm{C}$. The anti-rEtATG8 antibody (diluted 1:500) and donkey anti-rabbit IgG-R (diluted 1:400, SantaCruz Biotechnology, USA) were incubated successively with the parasites for $1 \mathrm{~h}$ at $37^{\circ} \mathrm{C}$. Parasitic DNA was labeled for 5 min with DAPI solution $(10 \mu \mathrm{g} / \mathrm{mL}$, Beyotime, China). All images were acquired with a Zeiss LSM710 confocal system (CarlZeiss). 


\section{Results}

\section{Morphological evidence of autophagosomes in E. tenella}

To confirm the autophagy of $E$. tenella under starvation, we examined the subcellular ultrastructure of $E$. tenella sporozoites by TEM. The results showed that there were some food vacuoles (FV) in the sporozoites cytoplasm without autophagosome-like structure after been treated with DMEM, (Figure 1A). After starvation in HBSS, more FV (Figure 1B) were formed in sporozoite compared to DMEM control, and a double membrane autophagosome in the sporozoite is marked as a red solid arrow, which contains partially digested material (Figure 1B), including some degraded materials (damaged organelles).
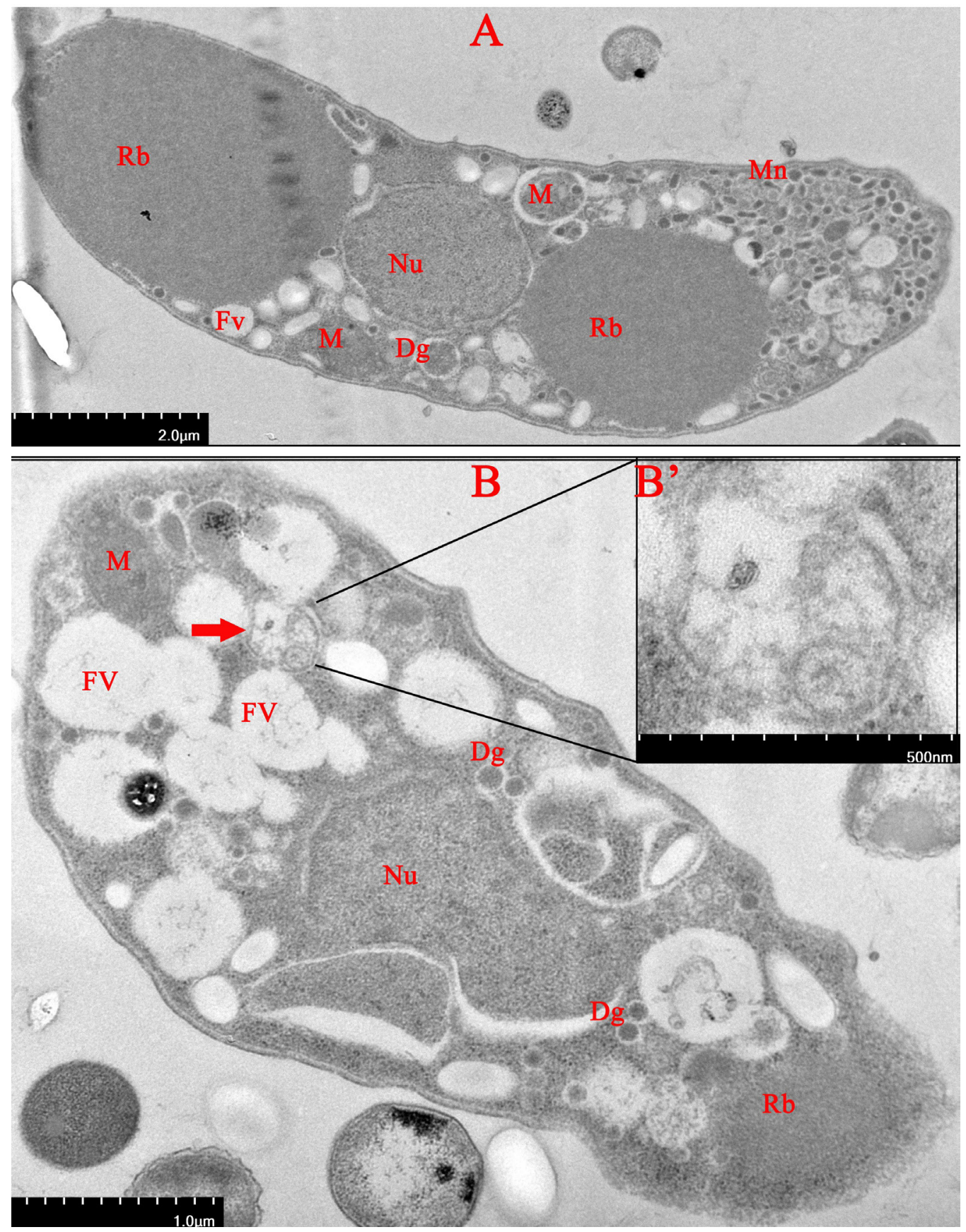

Figure 1. Morphological observation of autophagosomes in E. tenella sporozoites by transmission electron microscopy. A, Normal sporozoite under DMEM. B, Sporozoites starved for $8 \mathrm{~h}$ in HBSS medium, the double membrane autophagosome is marked in red solid arrow, which contains partially digested material. B', The magnification of B. In Figure 1 A, B and B': Nu: nucleus; Mn, microneme; Fv, food vacuole; M, mitochondrion; $\mathrm{Dg}$, dense granule; Rb, refractive body. 


\section{Cloning and characterization of Etatg8}

The ortholog of the atg8 gene (ETH_00016760) in E. tenella genome database was identified as 375-bp open reading frame (Figure $2 \mathrm{~A}$ ), which encodes a protein of 124 amino acid residues. Bioinformatics software analyses showed that the Etatg8 gene encodes non-secreted protein, without signal peptide (Figure 2B) and transmembrane domain (Figure 2D), and it is most likely located in the parasite's cytoplasm (Figure 2C). In the phylogenetic tree established by NJ method, all Eimeria species clustered on one branch, and had the closest genetic relationship with other apicomplexan parasites (Figure 3). The SWISS-MODEL analysis indicated the highest quality of the model, where $90.8 \%$ of the residues were located in the most favored regions, $8.3 \%$ in the additionally-allowed regions, and $0.9 \%$ in the disallowed regions (Figure 4A). The EtATG8 structure (Figure 4B) was very similar to PfATG8 (Figure 4C), which contains four alpha helices and six beta sheets (Figure 4D), including two N-terminal alpha helices ( $\mathrm{a} 1$ and a2), a C-terminal ubiquitin-like domain, and two short beta strands ( $\beta 3$ and $\beta 4$ ) between $\alpha 3$ and $\beta 5$, where the domain (shown in blue frame) between $\alpha 1$ and $\alpha 3$ is the binding region for ATG3 (Figure 4E).
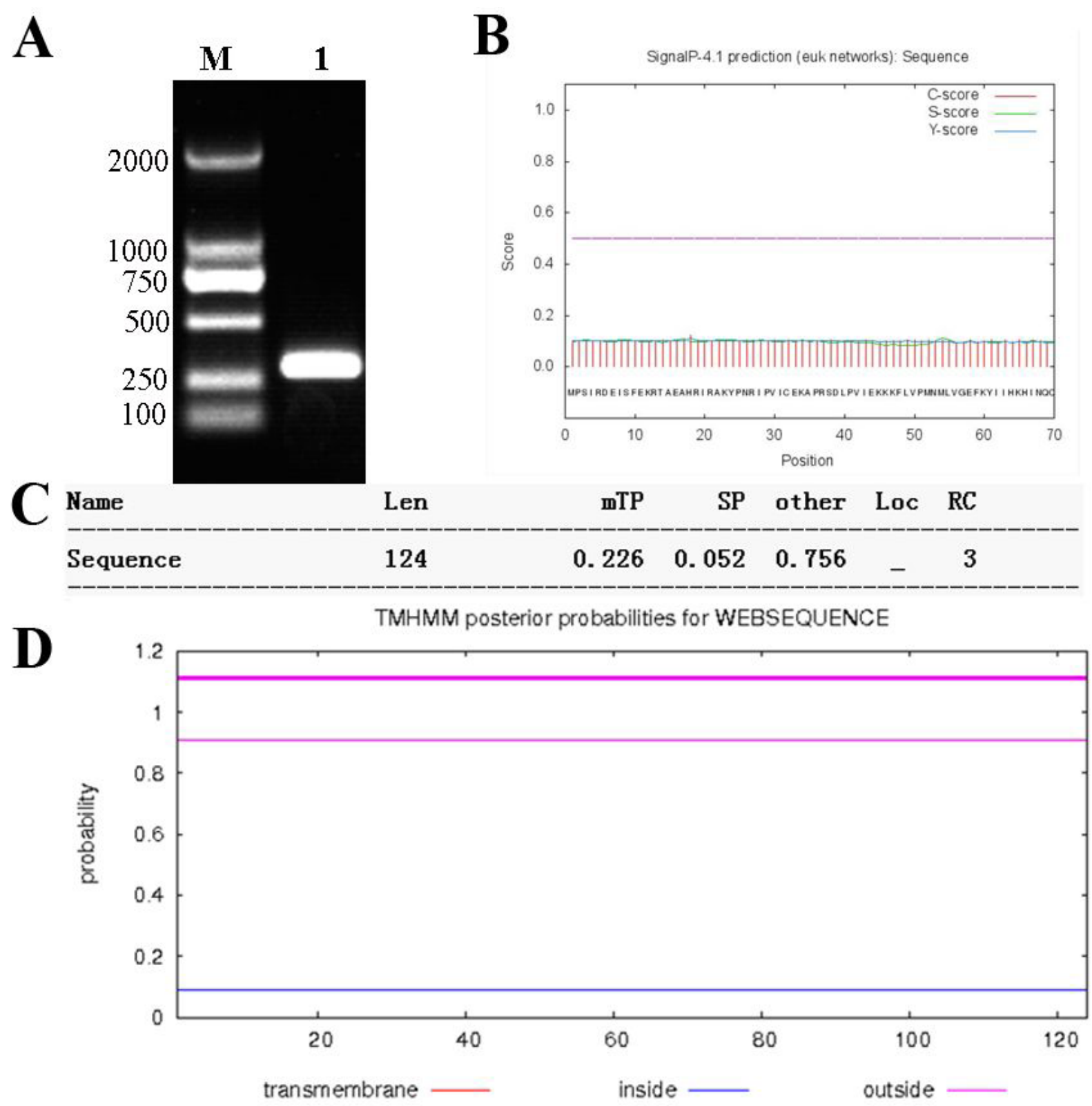

Figure 2. Sequence analysis of Etatg8 (solid arrow). A, RT-PCR product. M: DL2000 DNA marker; 1: Etatg8. B, Prediction of signal peptide cleavage sites. C-score: raw cleavage site score; S-score: signal peptide score; Y-score: combined cleavage site score. C, Prediction of subcellular location. " " represented any other location except C (chloroplast, as apicoplast in apicomplexan), M (mitochondrion) and S (secretory pathway). D, Prediction of transmembrane helices in proteins. Red line: transmembrane domain; blue line: inside domain; ink line: outside domain. 


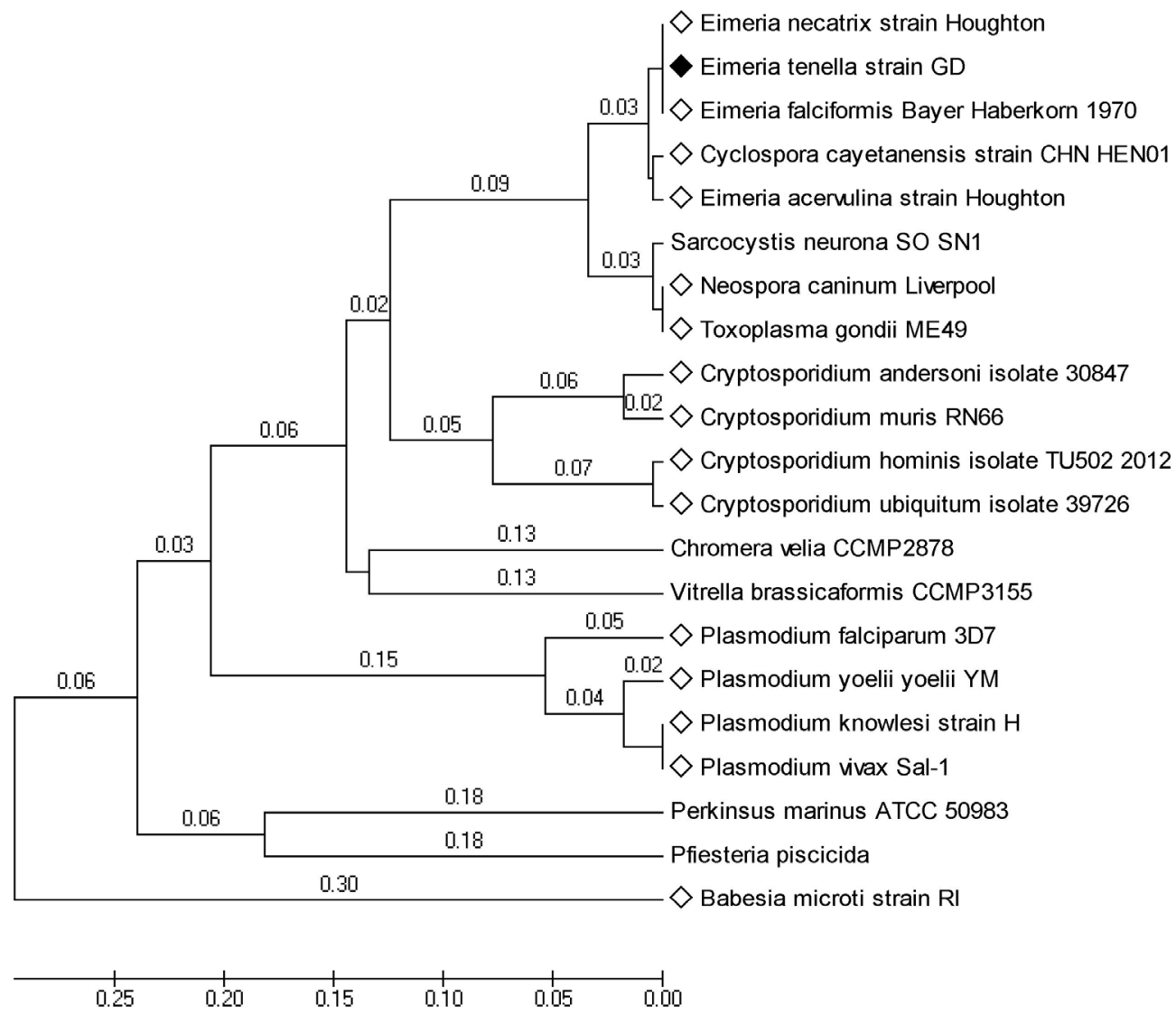

Figure 3. The phylogenetic tree of EtATG8 proteins. Solid diamond: the EtATG8 protein from E. tenella GD strain; hollow diamond: the apicomplexa cluster.

A

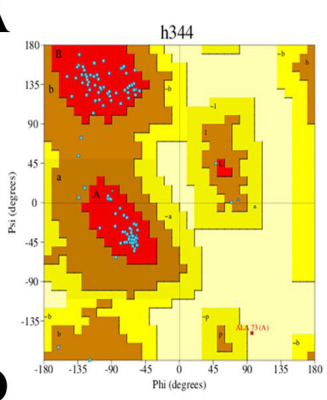

D

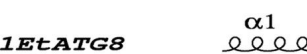

B

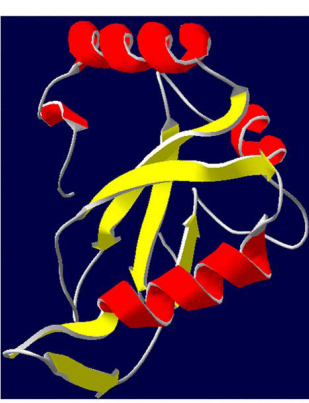

$\alpha 2$
C

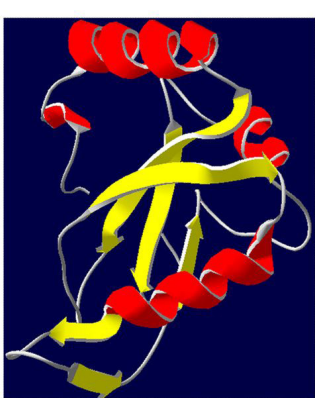

$\beta 1$

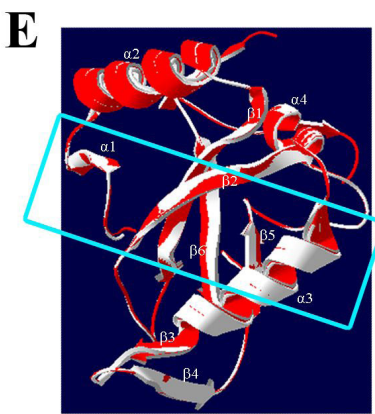

B2 1EtATG8 MPSIRDEISFEKRTAFAHRIRAKYPNRIPVICFKAPRSDIPVIFKKKEIVPMNMIVGEFK

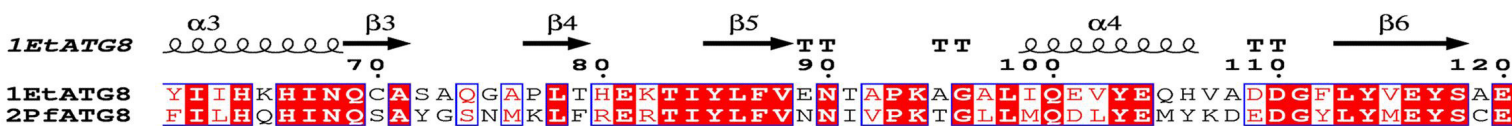

\section{EtATG8 \\ $\begin{array}{ll}\text { 1EtATG8 } & \text { NTIG } \\ \text { 2PIATG8 } & \text { STLG }\end{array}$}

Figure 4. The tertiary structure prediction of EtATG8. A, Ramachandran plot of the 3D model of EtATG8. B, The homology modeling of structure of EtATG8. C, The structure of PfATG8. D, Clustalw analysis of the protein sequences of EtATG8 and PfATG8. E, Comparative protein structure of EtATG8 (White) and PfATG8 (Red), the binding region of ATG3 is shown in blue frame. Yellow: Beta sheets; Red: alpha helices. 


\section{Expression and purification of rEtATG8}

The rEtATG8 expressed under induction with $1 \mathrm{mM}$ isopropyl $\beta$-D-1- thiogalactopyranoside, was identified as a band of about $18 \mathrm{kDa}$ on $12 \%$ SDS-PAGE gel (Figure 5A). The purified proteins were obtained from the bacterial lysates using a Ni-NTA chromatography column, and a specific band around the 18kDa size was detected by Western blot using the anti-His-Tag monoclonal antibody against His-tagged rATG8(Figure 5B).

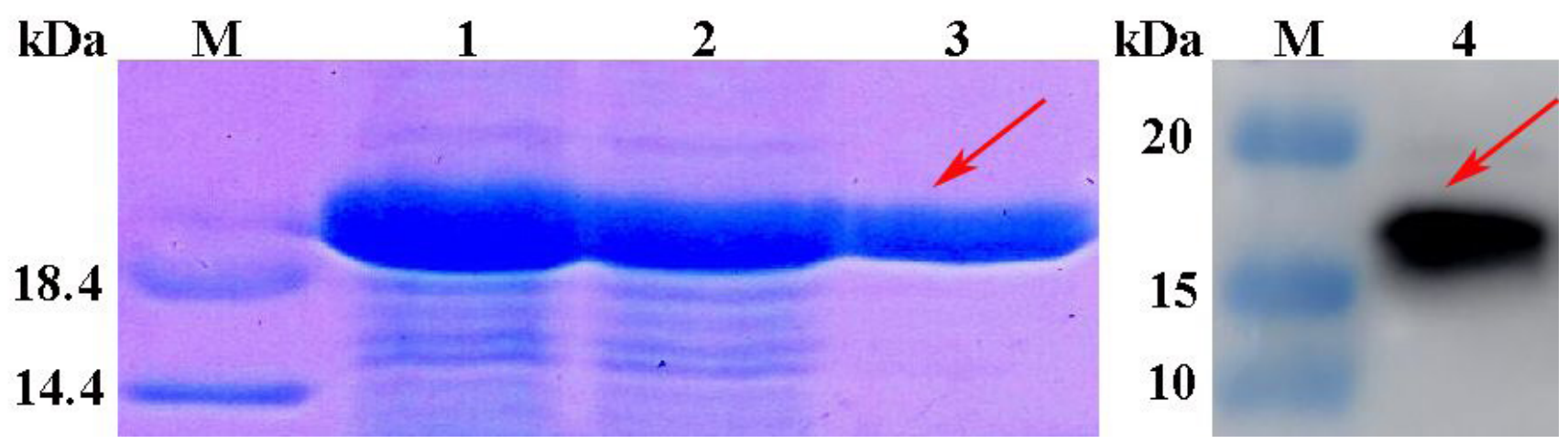

Figure 5. SDS-PAGE and Western bolt analysis for EtATG8 (solid arrow) cloned in pET28a and expressed in BL21(DE3) strain. M1, protein marker. $\mathrm{M} 2$, Western blot marker. 1, cell lysate with induction for $4 \mathrm{~h}$ at $37^{\circ} \mathrm{C} .2$, debris of cell lysate with induction for $4 \mathrm{~h}$ at $37^{\circ} \mathrm{C}$. 3, Purified protein. 4, Western Blot analysis of the EtATG8. The primary antibody for western blot is anti-His antibody.

\section{Transcriptional profile of Etatg8 in four stages of E. tenella}

The RT-qPCR results showed that the transcription level of Etatg8 was highest at the unsporulated oocyst stage (Figure 6), which was about 200 times higher than that in the merozoite stage, but less than 10 times higher than those in the sporulated oocyst and sporozoite stages $(p<0.05)$.

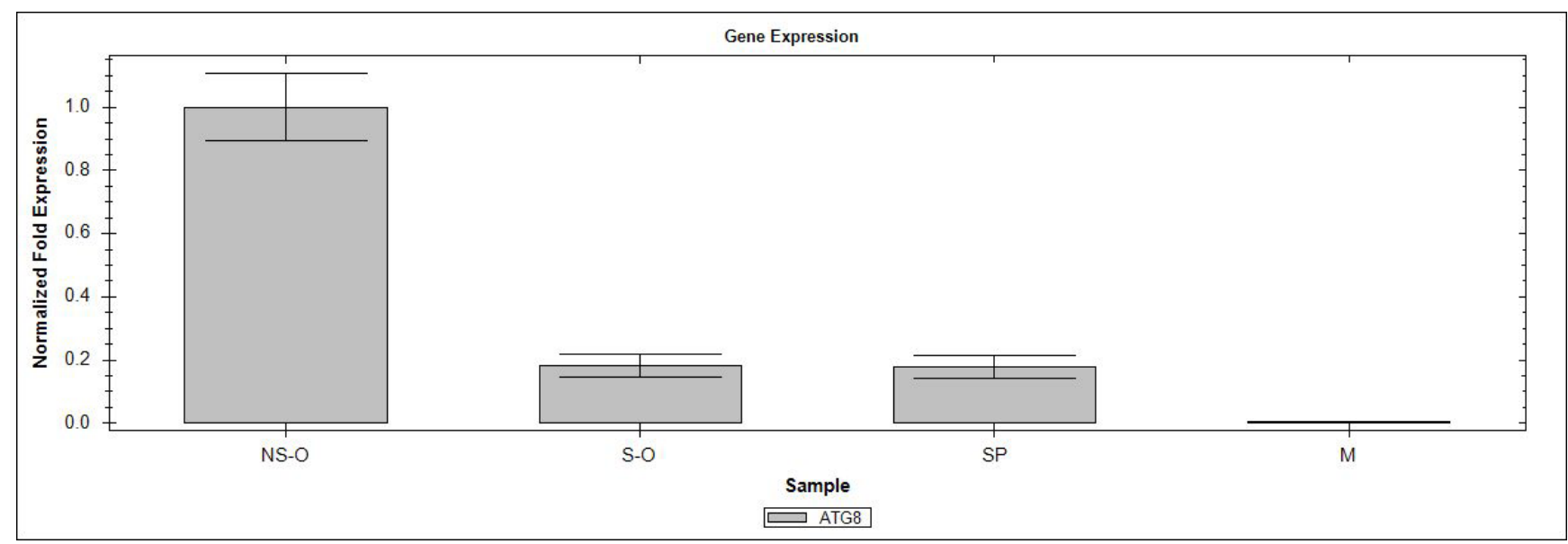

Figure 6. Transcription profiles of Etatg8 in four life stages of E. tenella. The transcription profile in unsporulated oocysts (NS-O), sporulated oocysts (S-O), sporozoites (SP) and merozoites (M) were normalized to the 18S rRNA level of the corresponding stage. $p<0.05, \mathrm{n}=3$.

\section{Protein expressional profile of EtATG8 in four stages of E. tenella}

The protein expressional profiles in unsporulated oocysts (NS-O), sporulated oocysts (S-O), sporozoites (SP) and merozoites $(\mathrm{M})$ were normalized to the EtActin level of the corresponding stage. The WB results revealed that anti-actin antibodies labeled the same bands of $42 \mathrm{kDa}$ in US-O, S-O, SP and the M stage, the EtATG8 ratio to EtActin were about 0.8 (in NS-O), 1.03 (in S-O), 0.92 (in SP) and 0.91 (in M). In addition, no significant difference in the expression level of EtATG8/EtActin was observed (Figure 7). 


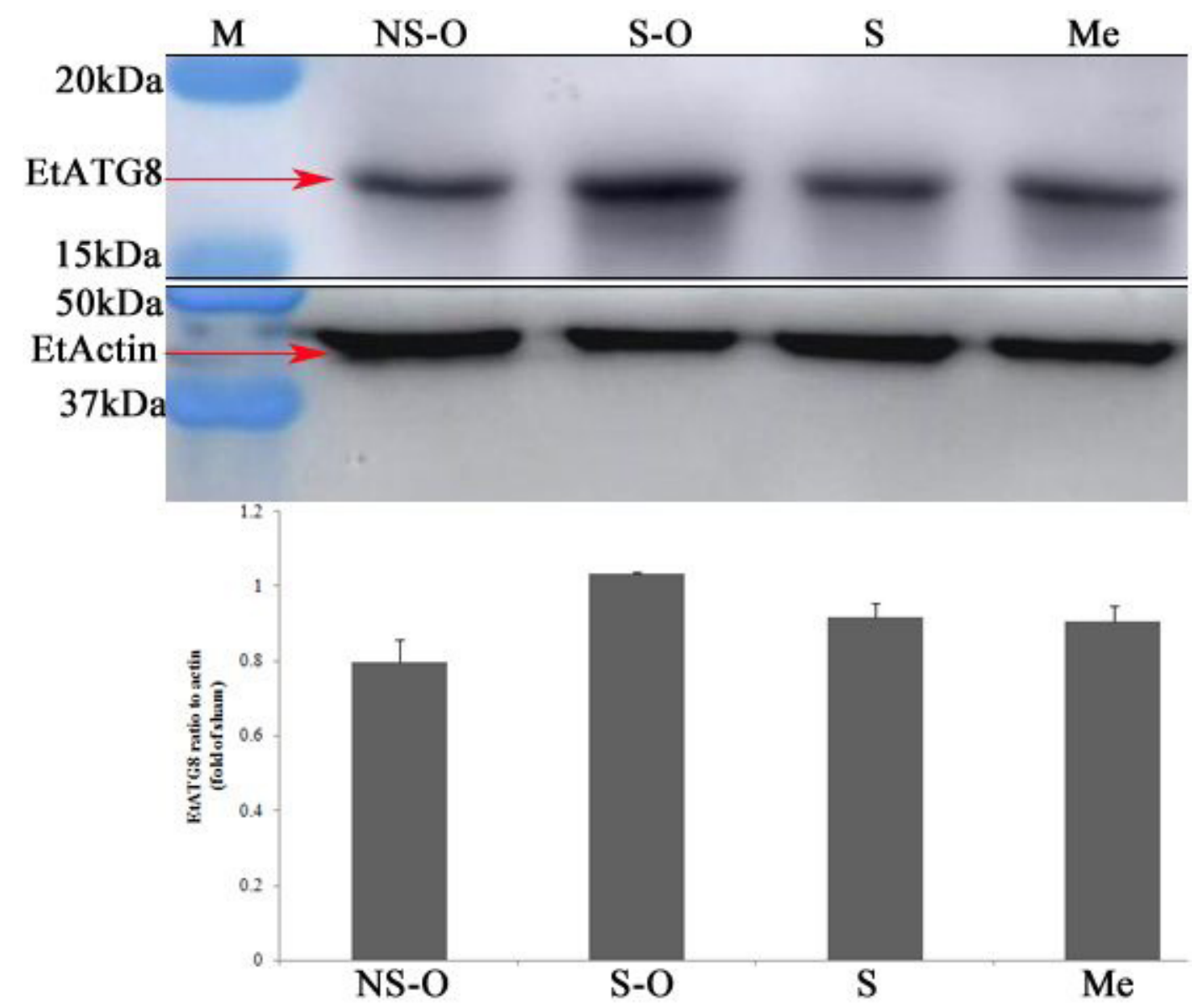

Figure 7. Protein expressional profiles of EtATG8 in four life stages of E. tenella. A, The protein expressional profiles in unsporulated oocysts (NS-O), sporulated oocysts (S-O), sporozoites (SP) and merozoites (Me) were normalized to the EtActin level of the corresponding stage. B, The quantified densitometric analysis of EtATG8.

\section{EtATG8 of E. tenella sporozoites was lipidated under different conditions}

The results showed that EtATG8 could be separated into a single band of about $14 \mathrm{kDa}$ by SDS-PAGE without urea under starvation (HBSS) condition (Figure 8A, upper), whereas it could be separated into non-lipidated (form I) and lipidated (form II) proteins by SDS-PAGE with $6 \mathrm{M}$ urea (Figure 8A, middle). However, form II-EtATG8 increased significantly in the presence of inducer RP or under starvation condition than other groups (Figure 8A, middle). After starvation for $8 \mathrm{~h}$, the ratio of form II/form I was about 0.44 , which was significantly higher than that in HBSS + 3-MA group (0.07) and DMEM control group (Figure 8B). The ratio of form II/form I in DMEM+RP group was about 0.63 (Figure 8B), which was higher than that in DMEM+RP+3-MA group (0.28) and DMEM control group.

\section{Subcellular location of EtATG8 in the sporozoites and merozoites}

Subcellular location of EtATG8 in the sporozoites or merozoites was shown in Figure 9A and 9B. The results showed that EtATG8 signals were aggregated in the sporozoite cytoplasm after incubation in HBSS (Fig. 9A2), DMEM+RP (Fig. 9A3) or DMEM+Mon (Fig. 9A4), while they were evenly distributed throughout sporozoites after incubation in DMEM control (Fig. 9A1), and the EtATG8 signals were aggregated in the merozoites cytoplasm after incubation in HBSS (Figure 9 B2), DMEM+RP (Figure 9 B3) or DMEM+Mon (Figure 9 B4), while they were evenly distributed throughout merozoites after incubation in DMEM control (Figure 9 B1).

\section{Discussion}

In recent years, researches on autophagy have shown the importance of this process in the survival of apicomplexan parasites (Nguyen et al., 2017). The ATG8, as a marker for detection of autophagosomes, plays an 


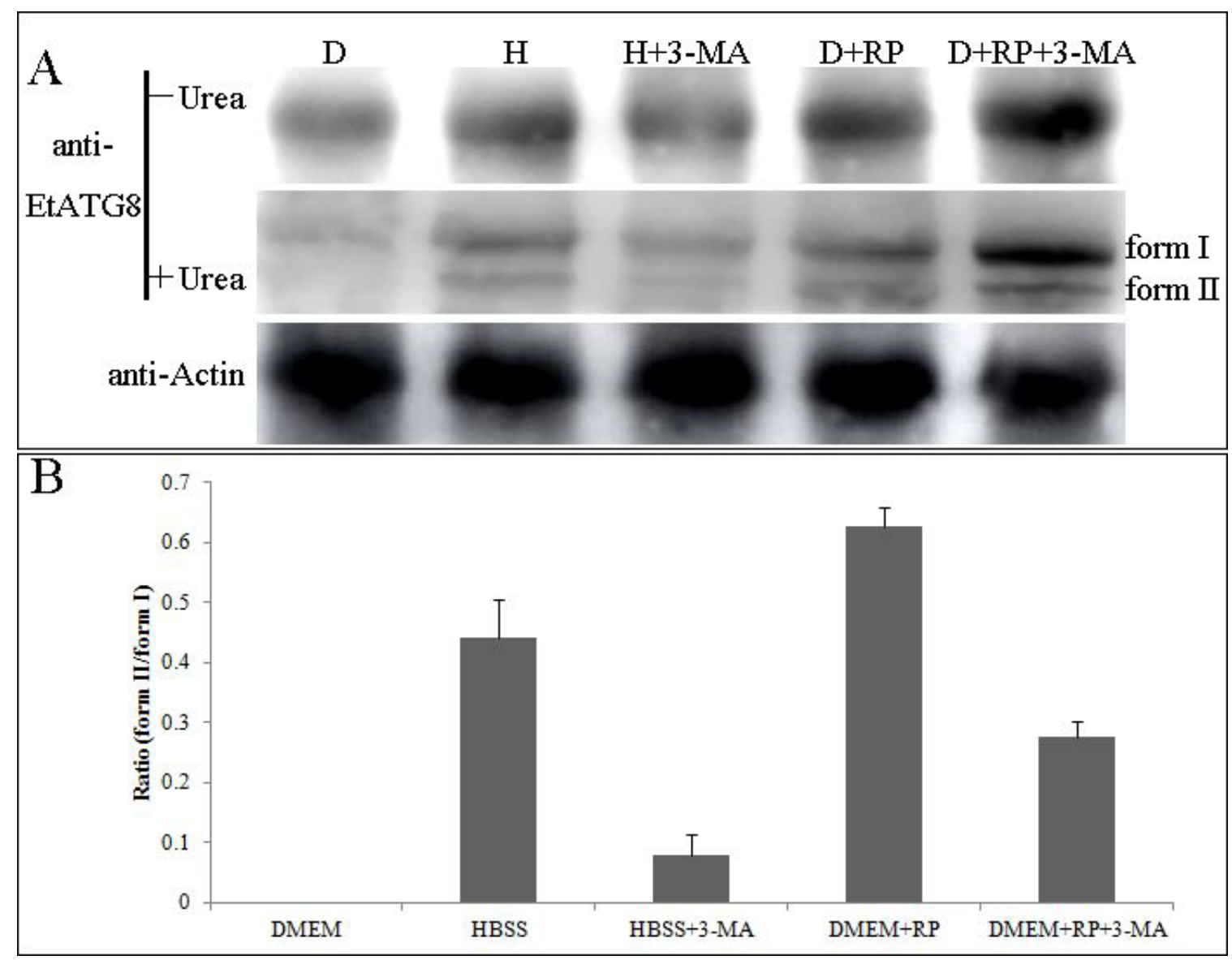

Figure 8. Western blot analysis for EtATG8 of E. tenella sporozoites under different conditions. A, E. tenella sporozoites under complete DMEM (D), HBSS (H), HBSS with 3-MA (H+3-MA), DMEM with RP (D+RP) and DMEM with RP and 3-MA (D+RP+3-MA). The total proteins were fractionated in 12\% SDS-PAGE with $6 \mathrm{M}$ urea (+Urea) or without (-Urea). The primary antibody for western blot was anti-EtATG8 antibody or anti-Actin antibody. B, The quantification of EtATG8 intensities shown in A. The ratio of form II-EtATG8 /form I- EtATG8 was presented as mean \pm SD of three independent experiments.

important role in the study of parasite autophagy. In the present study, the Etatg8 gene was cloned, sequenced and analyzed by bioinformatics tools, an anti-EtATG8 specific antibody was produced against recombinant EtATG8 recognized an $18 \mathrm{kDa}$ native protein by WB. The autophagosomes of $E$. tenella sporozoites were detected by TEM and the expression levels of EtATG8 proteins were analyzed during four developmental stages of E.tenella. The expression profiles of EtATG8 under autophagy induction conditions and its subcellular localization in sporozoites and merozoites were also studied.

During the complex mechanism of autophagy, autophagosome formation is a key step, which results in enclosure of materials to be degraded for delivery to the lysosome (Ichimura et al., 2000; Tooze \& Yoshimori, 2010). In the present study, the autophagosome-like structure with bilayer membranes is prominent under TEM in the $E$. tenella sporozoites, the expression of EtATG8 protein in starvation- or inducer- induced sporozoites was detected by WB, and the results have shown that EtATG8 was lipidated under these conditions, which provide evidence for formation of stress-induced autophagosomes in Eimeria. Sequence analysis of the Etatg8 gene has revealed that it is highly conserved, and encodes a typical non-secreted, ubiquitin-like protein without transmembrane domain. The homology modeling showed that EtATG8 has a conserved three-dimensional structure and a similar binding region of ATG3 to ATG8 of $P$. falciparum, which provides indirect evidence that EtATG8 plays a similar role in the formation of $E$. tenella autophagosome.

Autophagy plays an important role during cell differentiation and development (Qi et al., 2019). In this study, we found that Etatg8 mRNA levels in the unsporulated oocysts stage were significantly higher than those in the other three developmental stages. These results are consistent with the analysis of the coccidial transcriptome in EuPathDB (ETH_00016760). We predict that autophagy has an important role in the sporulation of oocysts, which requires 


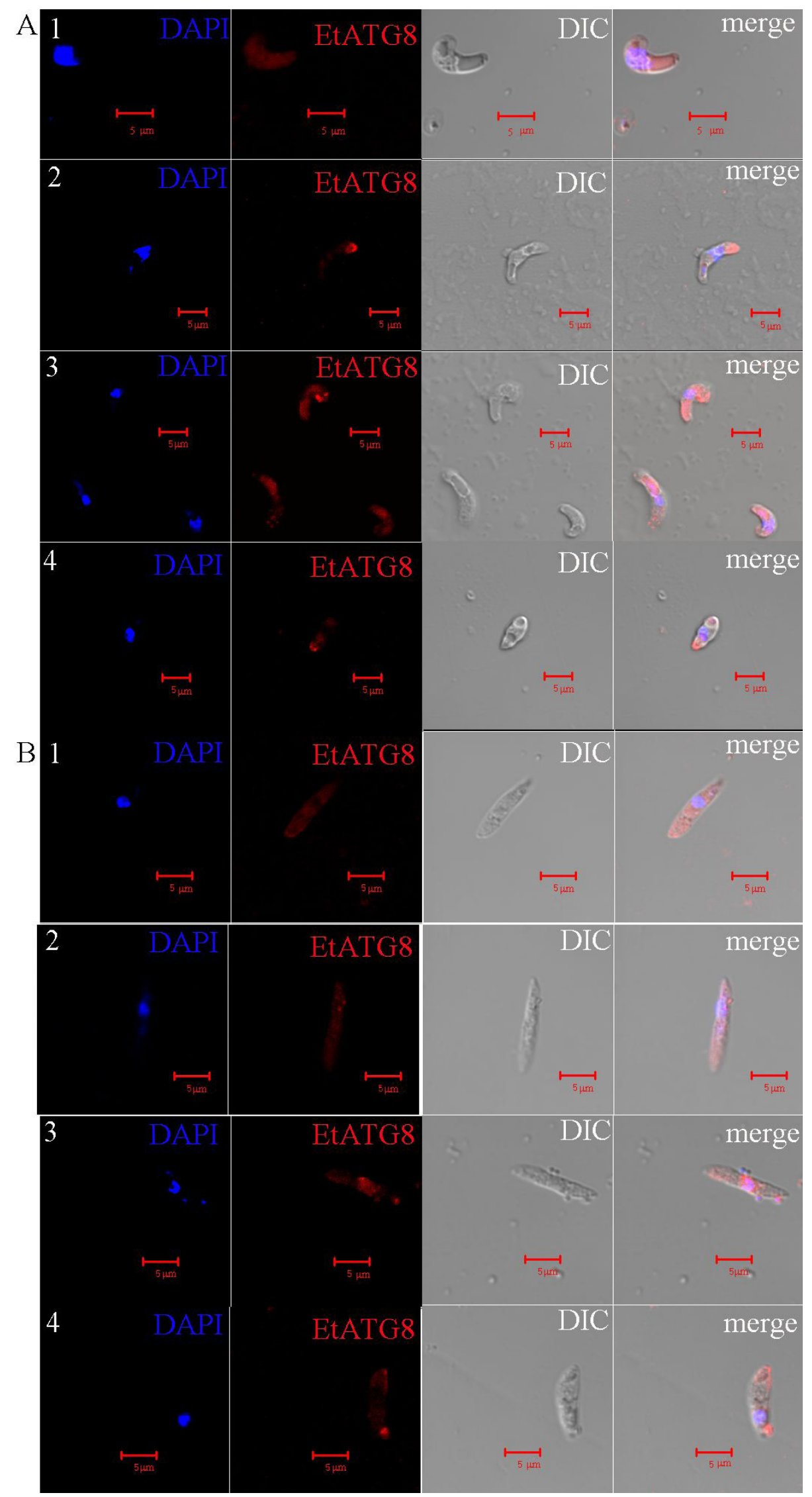

Figure 9. Localization of EtATG8 in sporozoites and merozoites. A, Localization of EtATG8 in sporozoite. 1: under complete DMEM; 2: under HBSS; 3: under DMEM + RP; 4: under DMEM + Mon. B, Localization of EtATG8 in merozoite. 1: under complete DMEM; 2: under HBSS; 3: under DMEM + RP; 4: under DMEM + Mon. 
the storage of a large number of atg8 mRNAs to express enough ATG8 proteins for autophagosome formation. However, the expression levels of EtATG8 protein during four developmental stages were inconsistent with the results of mRNA levels. This may be due to two reasons: (1) post-transcriptional processing and modification of the Etatg8 gene, including transcriptional degradation, results in inconsistent levels of transcription and expression; (2) the expression process of EtATG8 protein would maintain at a stable level during all the developmental stages, and would show variation only when undergoing cell differentiation. These hypotheses need further investigations.

The subcellular presence of ATG8 in yeast and mammalian cells have shown it's localization in the cytoplasm (Lévêque et al., 2015), whereas in case of T. gondii and P. falciparum, ATG8 is localized in the apicoplast membrane (Kitamura et al., 2012). Here, we investigated the subcellular localization of EtATG8 in sporozoites and merozoites, and found that it is generally distributed in the cytoplasm of the E. tenella parasites in DMEM cultures. After treatment with HBSS, monensin or rapamycin, EtATG8 gathered in the cytoplasm of these parasites.

\section{Conclusions}

To summarize, we successfully cloned and expressed the autophagy marker protein gene (Etatg8) from unsporulated and sporulated oocyst, sporozoite and merozoite developmental stages of E. tenella (EtATG8). It was confirmed that E.tenella sporozoites can form autophagosomes after induction either by starvation or autophagy inducer, EtATG8 protein is lipidated and accumulates in sporozoite and merozoite cytoplasm, while autophagy inhibitor (3-MA) can inhibit the production of sporozoite autophagosomes. These findings confirmed a conserved autophagy mechanism in E. tenella, and also have proven that ATG8 can be used as a marker protein for autophagy research in avian coccidia, which will serve as a basis for future investigations in this field.

\section{Acknowledgements}

We thank Jianfei Zhang (Institute of Animal Health, Guangdong Academy of Agricultural Sciences) and Guan Zhu (Department of Veterinary Pathobiology, College of Veterinary Medicine \& Biomedical Sciences, Texas A\&M University, College Station, Texas, United States of America) for excellent technical assistance, and Longxian Zhang (Henan Agricultural University) and Xiangrui Li (Nanjing Agricultural University) for helpful advice and comments on earlier versions of this work. This work was supported by National Key Research and Development Program of China (2016YFD0501303), NSFC grants (31872460, 31672541), Rural Revitalization Special Strategic Project of Guangdong (201817SY0003), NSF grant of Guangdong province (2019A1515010913), Guangdong Provincial Special Fund for Modern Agriculture Industry Technology Innovation Teams (2020KJ119), the Key Research and Development Program of Guangdong Province (2019B020218004), Special fund for scientific innovation strategy-construction of high level Academy of Agriculture Science (R2016PY-JX003, R2016PY-QY003, R2018QD-091, R2018QD-092), Discipline team construction projects of the 13th Five-year Plan.

\section{References}

Besteiro S, Brooks CF, Striepen B, Dubremetz JF. Autophagy protein Atg3 is essential for maintaining mitochondrial integrity and for normal intracellular development of Toxoplasma gondii tachyzoites. PLoS Pathog 2011; 7(12): e1002416. http://dx.doi. org/10.1371/journal.ppat.1002416. PMid:22144900.

Besteiro S. Which roles for autophagy in Toxoplasma gondii and related apicomplexan parasites? Mol Biochem Parasitol 2012; 184(1): 1-8. http://dx.doi.org/10.1016/j.molbiopara.2012.04.001. PMid:22515957.

Besteiro S. Autophagy in apicomplexan parasites. Curr Opin Microbio/ 2017; 40: 14-20. http://dx.doi.org/10.1016/j.mib.2017.10.008. PMid:29096193.

Blake DP, Tomley FM. Securing poultry production from the ever-present Eimeria challenge. Trends Parasitol 2014; 30(1): 12-19. http://dx.doi.org/10.1016/j.pt.2013.10.003. PMid:24238797.

Brennand A, Gualdrón-López M, Coppens I, Rigden DJ, Ginger ML, Michels PAM. Autophagy in parasitic protists: unique features and drug targets. Mol Biochem Parasito/ 2011; 177(2): 83-99. http://dx.doi.org/10.1016/j.molbiopara.2011.02.003. PMid:21315770.

Clark EL, Tomley FM, Blake DP. Are Eimeria Genetically diverse, and does it matter? Trends Parasito/ 2017; 33(3): 231-241. http:// dx.doi.org/10.1016/j.pt.2016.08.007. PMid:27593338.

Ichimura Y, Kirisako T, Takao T, Satomi Y, Shimonishi Y, Ishihara N, et al. A ubiquitin-like system mediates protein lipidation. Nature 2000; 408(6811): 488-492. http://dx.doi.org/10.1038/35044114. PMid:11100732. 
Jiang L, Lin J, Han H, Dong H, Zhao Q, Zhu S, et al. Identification and characterization of Eimeria tenella apical membrane antigen-1 (AMA1). PLoS One 2012; 7(7): e41115. http://dx.doi.org/10.1371/journal.pone.0041115. PMid:22829917.

Kitamura K, Kishi-Itakura C, Tsuboi T, Sato S, Kita K, Ohta N, et al. Autophagy-related Atg8 localizes to the apicoplast of the human malaria parasite Plasmodium falciparum. PLoS One 2012; 7(8): e42977. http://dx.doi.org/10.1371/journal.pone.0042977. PMid:22900071.

Latré de Laté P, Pineda M, Harnett M, Harnett W, Besteiro S, Langsley G. Apicomplexan autophagy and modulation of autophagy in parasite-infected host cells. Biomed J 2017; 40(1): 23-30. http://dx.doi.org/10.1016/j.bj.2017.01.001. PMid:28411879.

Lévêque MF, Berry L, Cipriano MJ, Nguyen H, Striepen B, Besteiro S. Autophagy-related protein ATG8 has a noncanonical function for apicoplast inheritance in Toxoplasma gondii. MBio 2015; 6(6): e1446. http://dx.doi.org/10.1128/mBio.01446-15. PMid:26507233.

Liu D, Cao L, Zhu Y, Deng C, Su S, Xu J, et al. Cloning and characterization of an Eimeria necatrix gene encoding a gametocyte protein and associated with oocyst wall formation. Parasit Vectors 2014; 7(1): 27. http://dx.doi.org/10.1186/1756-3305-7-27. PMid:24428893.

Liu R, Ma X, Liu A, Zhang L, Cai J, Wang M. Identification and characterization of a cathepsin-L-like peptidase in Eimeria tenella. Parasitol Res 2014; 113(12): 4335-4348. http://dx.doi.org/10.1007/s00436-014-4107-2. PMid:25248513.

Meijer WH, Van Der Klei IJ, Veenhuis M, Kiel JA. Kiel JA. ATG genes involved in non-selective autophagy are conserved from yeast to man, but the selective Cvt and pexophagy pathways also require organism-specific genes. Autophagy 2007; 3(2): $106-116$. http://dx.doi.org/10.4161/auto.3595. PMid:17204848.

Mizushima N, Yoshimori T, Levine B. Methods in mammalian autophagy research. Cell 2010; 140(3): 313-326. http://dx.doi. org/10.1016/j.cell.2010.01.028. PMid:20144757.

Nguyen HM, Hajj HE, Hajj RJ, Tawil N, Berry L, Lebrun M, et al. Toxoplasma gondii autophagy-related protein ATG9 is crucial for the survival of parasites in their host. Cell Microbio/ 2017; 19(6): e12712. http://dx.doi.org/10.1111/cmi.12712. PMid:27992947.

Peek HW, Landman WJM. Coccidiosis in poultry: anticoccidial products, vaccines and other prevention strategies. Vet Q 2011; 31(3): 143-161. http://dx.doi.org/10.1080/01652176.2011.605247. PMid:22029884.

Qi NS, Wang YY, Liao SQ, Wu CY, LV MN, Li J, et al. Partial protective of chickens against Eimeria tenella challenge with recombinant EtMIC-1 antigen. Parasitol Res 2013; 112(6): 2281-2287. http://dx.doi.org/10.1007/s00436-013-3389-0. PMid:23559377.

Qi N, Liao S, Abuzeid AMI, Li J, Wu C, Lv M, et al. The effect of autophagy on the survival and invasive activity of Eimeria tenella sporozoites. Sci Rep 2019; 9(1): 5835. http://dx.doi.org/10.1038/s41598-019-41947-y. PMid:30967577.

Quiroz-Castañeda RE, Dantán-González E. Control of Avian Coccidiosis: future and present natural alternatives. BioMed Res Int 2015; 2015: 430610. http://dx.doi.org/10.1155/2015/430610. PMid:25785269.

Sinai AP, Roepe PD. Autophagy in Apicomplexa: a life sustaining death mechanism? Trends Parasito/ 2012; 28(9): 358-364. http:// dx.doi.org/10.1016/j.pt.2012.06.006. PMid:22819059.

Sun M, Liao S, Zhang L, Wu C, Qi N, Lv M, et al. Molecular and biochemical characterization of Eimeria tenella hexokinase. Parasitol Res 2016; 115(9): 3425-3433. http://dx.doi.org/10.1007/s00436-016-5104-4. PMid:27150971.

Tamura K, Peterson D, Peterson N, Stecher G, Nei M, Kumar S. MEGA5: molecular evolutionary genetics analysis using maximum likelihood, evolutionary distance, and maximum parsimony methods. Mol Biol Evol 2011; 28(10): 2731-2739. http://dx.doi. org/10.1093/molbev/msr121. PMid:21546353.

Tan L, Li Y, Yang X, Ke Q, Lei W, Mughal MN, et al. Genetic diversity and drug sensitivity studies on Eimeria tenella field isolates from Hubei Province of China. Parasit Vectors 2017; 10(1): 137. http://dx.doi.org/10.1186/s13071-017-2067-y. PMid:28274278.

Tang X, Wang C, Liang L, Hu D, Zhang S, Duan C, et al. Co-immunization with two recombinant Eimeria tenella lines expressing immunoprotective antigens of E. maxima elicits enhanced protection against E. maxima infection. Parasit Vectors 2019; 12(1): 347. http://dx.doi.org/10.1186/s13071-019-3605-6. PMid:31300007.

Tewari AK, Maharana BR. Control of poultry coccidiosis: changing trends.J Parasit Dis 2011; 35(1): 10-17. http://dx.doi.org/10.1007/ s12639-011-0034-7. PMid:22654309.

Tomlins AM, Ben-Rached F, Williams RA, Proto WR, Coppens I, Ruch U, et al. Plasmodium falciparum ATG8 implicated in both autophagy and apicoplast formation. Autophagy 2013; 9(10): 1540-1552. http://dx.doi.org/10.4161/auto.25832. PMid:24025672.

Tooze SA, Yoshimori T. The origin of the autophagosomal membrane. Nat Cell Bio/ 2010; 12(9): 831-835. http://dx.doi.org/10.1038/ ncb0910-831. PMid:20811355.

Walczak M, Ganesan SM, Niles JC, Yeh E. ATG8 is essential specifically for an autophagy-independent function in Apicoplast biogenesis in blood-stage malaria parasites. MBio 2018; 9(1): e02021-17. http://dx.doi.org/10.1128/mBio.02021-17. PMid:29295911.

Xu JH, Qin ZH, Liao YS, Xie MQ, Li AX, Cai JP. Characterization and expression of an actin-depolymerizing factor from Eimeria tenella. Parasitol Res 2008; 103(2): 263-270. http://dx.doi.org/10.1007/s00436-008-0961-0. PMid:18409026. 
ATG8, a marker of Eimeria tenella autophagy

Yamaguchi M, Noda NN, Nakatogawa H, Kumeta H, Ohsumi Y, Inagaki F. Autophagy-related protein 8 (Atg8) family interacting motif in Atg3 mediates the Atg3-Atg8 interaction and is crucial for the cytoplasm-to-vacuole targeting pathway. J Bio/ Chem 2010; 285(38): 29599-29607. http://dx.doi.org/10.1074/jbc.M110.113670. PMid:20615880.

Yu L, Chen Y, Tooze SA. Autophagy pathway: Cellular and molecular mechanisms. Autophagy 2018; 14(2): 207-215. http://dx.doi. org/10.1080/15548627.2017.1378838. PMid:28933638. 


\section{Erratum}

In the article "Identification and Characterization of the ATG8, a Marker of Eimeria tenella Autophagy", DOI number https://doi.org/10.1590/s1984-29612021002, published in Brazilian Journal of Veterinary Parasitology, volume 30 , issue 1, 2021, e017020, which reads:

\section{Mudassar Mohiuddin}

${ }^{1}$ Key Laboratory of Livestock Disease Prevention of Guangdong Province, Maoming Branch, Guangdong Laboratory for Lingnan Modern Agriculture, Scientific Observation and Experiment Station of Veterinary Drugs and Diagnostic Techniques of Guangdong Province, Ministry of Agriculture, Institute of Animal Health, Guangdong Academy of Agricultural Sciences, Guangzhou 510640, Guangdong, P. R. China

It should be read:

Mudassar Mohiuddin 1,3

${ }^{3}$ Department of Microbiology, Faculty of Veterinary and Animal Sciences, The Islamia University of Bahawalpur, Bahawalpur 63100, Pakistan 